Hitit Üniversitesi İlahiyat Fakültesi Dergisi / Journal of Divinity Faculty of Hitit University

ISSN 2651-3978 / e-ISSN 2636-8110

(Aralık/ December 2020) 19/2

\title{
PLATON FELSEFESINDE ADALET, DÜZEN VE YASA
}

\author{
Justice, ORder and LaW in Plato Philosophy
}

\section{SEBILE BAŞOK diş}

Doç. Dr., Necmettin Erbakan Üniversitesi, Sosyal ve Beșeri Bilimler Fakültesi, Felsefe Bölümü, Konya, Türkiye Asst. Prof. Sebile Başok Diş, Necmettin Erbakan University, Faculty of Social Sciences and Humanities, Department of Philosophy, Konya, Turkey

sebile_basok2000@yahoo.com

orcid.org/0000-0003-1960-697X

\begin{tabular}{|rl}
\hline MAKALE BILGISI & ARTICLE INFORMATION \\
Makale Türü & Article Types \\
\hline Araştırma Makalesi & Research Article \\
Geliş Tarihi & Received \\
13 Ağustos 2020 & 13 August 2020 \\
Kabul Tarihi & Accepted \\
9 Kasım 2020 & 9 November 2020 \\
Yayın Tarihi & Published \\
30 Aralık 2020 & 30 Aralık 2020 \\
Yayın Sezonu & Pub Date Season \\
Aralık & December \\
& Doi \\
\hline
\end{tabular}

https://doi.org/10.14395/hititilahiyat.779845

\section{ATIF/Cite AS:}

Diş, Sebile Başok, "Justice, Order and Law in Plato Philosophy” [Platon Felsefesinde Adalet, Düzen ve Yasa], Hitit Üniversitesi Illahiyat Fakültesi Dergisi-Journal of Divinity Faculty of Hitit University 19/2 (Aralık 2020), s. 1017-1046.

\section{İNTIHAL/PlagiarisM:}

Bu makale, en az iki hakem tarafından incelendi ve intihal içermediği teyit edildi.

This article has been reviewed by at least two referees and scanned via plagiarism software.

Copyright (C) Published by Hitit Üniversitesi, İlahiyat Fakültesi - Journal of Divinity Faculty of Hitit University, Çorum, Turkey. All rights reserved.

Makale dosvası

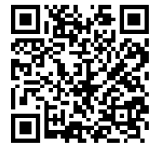




\title{
Justice, Order and Law in Plato Philosophy
}

\begin{abstract}
Plato scrutinized the concept of justice, which he perceived as an individual and social virtue, in a variety of his works, particularly in the Republic and the Laws, and tried to reveal what it is and its importance. The issue of justice is a difficult matter, and there are disagreements over what it is. Therefore, when Plato searched for an answer to the question of what it was, he also revealed what it was not. First of all, he opposed the views that justice is a manifestation of the will of the strong or is merely a means of protecting selfinterest. Justice is neither a manifestation of the will of the strong nor is it just means of protecting self-interest. Justice is a principle that surpasses even the gods. According to Plato, justice is an idea, similar to the idea of good.

For Plato, justice is not only an idea but also a virtue, and as a virtue, it is not detached from other virtues. Its existence associated with the existence of other virtues. In addition to justice, Plato deemed moderation, courage and wisdom as virtues and associated these virtues to the tripartite structure of the soul. According to Plato, who had adopted the tripartite understanding of the soul, apart from the rational part of the soul, there are parts of the soul that are irrational, which only desire and enrage. While the virtue of the rational part of the soul is wisdom, the virtues of other parts are moderation and courage. Justice is a virtue that emerges spontaneously when one has these three virtues. For this reason, there is no special part that corresponds to it in the soul.

According to Plato, societies, similar to the human spirit, consist of three parts, and each part corresponds to a part in the human soul. The producers correspond to the desiring part of the human soul, the guardian group corresponds to the enraging part of the soul, and the ruling class corresponds to the rational part of the soul. The virtues that these classes that make up the society must exhibit are the values that correspond to the parts of the soul. This means that the productive class must have the virtue of moderation, the auxiliary class must have the virtue of courage, and the guardian class must have the virtue of wisdom. If all classes fulfill their social roles with the virtue that is necessary for them, the society will become orderly, fair and happy. In order for society to have these qualities, the wise people who represent wisdom must rule. Because only these people can protect the goodness of society as a whole. Plato only considered societies that are ruled by rulers with wisdom as just societies and he evaluates the forms of government according to the virtu-
\end{abstract}


es possessed by their rulers. Societies that move away from the ideal state will gradually lose other virtues and distance themselves from justice.

For Plato, one of the most important duties of a ruler, who provides justice to his society, is legislation. Via laws, the officials involved in the administration of the state and the duties assigned to these administrators are determined, thereby establishing the operational mechanism of the state. Apart from that, laws act as tools to ensure that society is virtuous. The purpose of the law is the virtue, goodness and happiness of the society. Laws that are based on reason help citizens to garner virtue. People who obey the law will be able to establish friendly relations with each other.

In this study, it was attempted to demonstrate how Plato perceived justice, order and law, and how he relates these concepts to one other and other related concepts such as virtue, wisdom, happiness and punishment. Although there are many studies on Plato's views on justice, virtue and politics, there is no direct study in the Turkish literature on how he relates justice to concepts such as order, law and punishment. This study claims to fill a gap in the literature in this respect. In the study, what justice is not and its importance for Plato was mentioned first, and afterward, justice was discussed as an order in the aspects of individual soul and society, and finally, answers were sought for the questions of how to achieve individual and social justice. According to Plato, it has been concluded that individual and social happiness cannot be attained without the virtue of justice, wisdom is a necessity for justice, and laws are a means of achieving justice.

Keywords: History of Philosophy, Plato, Justice, Order, Law, Morality, Politics.

\section{Platon Felsefesinde Adalet, Düzen ve Yasa}

\section{Öz}

Platon, bireysel ve toplumsal bir erdem olarak gördüğ̈ü adaleti Devlet ve Yasalar adlı eserleri başta olmak üzere çeşitli eserlerinde soruşturmuş, onun ne olduğunu ve önemini ortaya koymaya çalışmıştır. Adaletin ne olduğu meselesi güç bir meseledir ve onun ne olduğu konusunda anlaşmazlıklar mevcuttur. Bu nedenle Platon, onun ne olduğu sorusuna yanit ararken, onun ne olmadığını da ortaya koymuştur. Öncelikli olarak o, adaletin güçlünün iradesinin tezahürü olduğu veya yalnızca özçıkarın korunması için bir araçtan ibaret olduğu görüşlerine karşı çıkmıştır. Adalet ne güçlünün iradesinin tezahürüdür ne de özçıkarın korunması için bir araçtan ibarettir. Adalet, tanrıla- 
rın bile üstünde yer alan bir ilkedir. Platon'a göre adalet, tıpkı iyi ideası gibi bir ideadır.

Platon için adalet bir idea olmanın yanı sıra ayrıca bir erdemdir ve bir erdem olarak diğer erdemlerden kopuk değildir. Onun varlığı diğer erdemlerin varlığıyla ilişkilidir. Adaletle beraber ölçülülük, cesaret ve bilgeliği de birer erdem olarak gören Platon, bu erdemleri ruhun üçlü yapısıyla ilişkilendirmiştir. Üç parçalı ruh anlayışını benimseyen Platon'a göre ruhun akıllı kısmı dışında, akıllı olmayan, arzulayan ve öfkelenen kısımları da bulunmaktadır. Ruhun akıllı kısmının erdemi bilgelikken, diğer kısımlarının erdemleri ölçülülük ve cesarettir. Adalet, bir kimsede bu üç erdemin bulunmasiyla kendiliğinden ortaya çıkan bir erdemdir. Bu nedenle onun ruhta tekabül ettiği herhangi özel bir kısım yoktur.

Platon'a göre insan ruhu gibi toplumlar da üç kısımdan oluşurlar ve her bir kısım, insan ruhundaki bir kısma tekabül eder. Üretici sınıf insan ruhunun arzulayan kısmına, koruyucu sınıf ruhun öfkelenen kısmına, yönetici sınıf ise ruhun akıllı kısmına karşılık gelir. Toplumu oluşturan bu sınıfların sergilemesi gereken erdemler de ruhun karşllık geldikleri kısımlarına uygun erdemlerdir. Bunun anlamı üretici sınıfın ölçülülük, koruyucu sınıfın cesaret, yönetici sınıfının ise bilgelik erdemine sahip olması gerektiğidir. Tüm sınıflar kendileri için gerekli erdeme sahip olarak toplumsal rollerini eksiksizce yerine getirdikleri takdirde, o toplum hem düzen kazanacak hem de adil ve mutlu bir toplum haline gelecektir. Toplumun bu niteliklere sahip olabilmesi için toplumu aklı temsil eden bilge kimselerin yönetmesi gerekmektedir. Çünkü ancak bu kişiler bir bütün olarak toplumun iyiliğini gözetebilirler. Yalnızca bilgelik sahibi yöneticilerin idare ettiği toplumu adil bir toplum sayan Platon, devlet biçimlerini toplumların sahip oldukları erdemler açısından değerlendirir. İdeal devletten uzaklaşan toplumlar aşama aşama diğer erdemleri de yitirecek ve adaletten de adım adım uzaklaşacaklardır.

Platon açısından topluma adalet sağlayacak olan yöneticinin en önemli görevlerinden biri de yasamadır. Yasalarla devlet idaresinde yer alan görevliler ve bunların görevleri belirlenerek devletin işleyiş mekanizması ortaya konur. Bunun dışında yasalar toplumun erdemli olmasını sağlayan araçlar olarak işlev görürler. Yasaların amacı toplumun erdemi, iyiliği ve mutluluğudur. Akıl kaynaklı olması gereken yasalar, yurttaşların erdem kazanmasına hizmet ederler. Yasalara itaat eden insanlar birbirleri ile dostane ilişkiler kurabileceklerdir.

Bu çalışmada başta Platon'un adalet, düzen ve yasadan ne anladığı, son- 
rasında ise bu kavramları birbirleriyle ve erdem, bilgelik, mutluluk, ceza gibi ilgili diğer kavramlarla nasıl ilişkilendirdiği gösterilmeye çalışılmıştır. Platon'un gerek adalet, gerekse de erdem ve siyaset ile ilgili görüşlerine ilişkin çok sayıda çalışma olmasına rağmen onun adalet ile düzen, yasa ve ceza gibi kavramları nasıl ilişkilendirdiğine dair doğrudan bir çalışma Türkçe literatürde bulunmamaktadır. Bu çalışma, bu bakımından literatürde bir boşluğu doldurma iddiasındadır. Çalışmada öncelikle Platon açısından adaletin ne olmadığına ve önemine değinilmiş; sonrasında adalet, bireysel ruhta ve toplumsal boyutta düzen olarak ele alınarak bireysel ve toplumsal adaletin nasıl sağlanacağı sorularına yanıt aranmıştır. Platon'a göre adalet erdemi olmadan bireysel ve toplumsal mutluluğa ulaşılamayacağı, adalet için bilgeliğin bir gereklilik olduğu, yasaların ise adalete ulaşmada birer araç olduğu sonuç olarak ortaya konmuştur.

Anahtar Kelimeler: Felsefe Tarihi, Platon, Adalet, Düzen, Yasa, Ahlak, Siyaset.

\section{Giriș}

Platon, Devlet ve Yasalar gibi oldukça önemli eserlerinde adalet, düzen ve yasa konularını ele almış ve bu konuları incelikli bir şekilde soruşturmuştur. Platon'un bu çalışmaları onun, felsefenin diğer alanlarında olduğu gibi siyaset felsefesinin de önemli filozofları arasında yer almasını sağlamıştır. Sokrates'in haksız bir şekilde idam edilmesinin kendisinde yarattığı etkiyle, ideal bir devletin nasıl olması gerektiğine yanıt arayan Platon, ideal devletin adil bir devlet olması gerektiği sonucuna ulaşmıştır. Çeşitli eserlerinde adaletin ne olduğunu soruşturan ve onun önemini belirten Platon, neyin adalet olmadığını da ortaya koymuş ve adaletsiz devletlerin niçin adaletsiz devletler olduğunu, bunların hangi tür devletler olduğunu göstererek açılamıştır.

Pek çok Antik Yunan filozofu gibi Platon için de felsefenin ana problemi, bir insana nasıl yaşaması gerektiğini gösterebilmektir. Mutluluğun en büyük değer olarak görüldüğü Antik Yunan felsefesinde ona nasıl ulaşılacağı filozofların başlıca ilgi konusu olmuş ve verilen yanıtlara göre farklı felsefe okulları teşekkül etmiştir. Platon da bir Antik Grek filozofu olarak bu konuya bigâne kalmamış, insanların hem bireysel hem de toplumsal olarak nasıl mutlu olabileceği sorusuna yanıt aramıştır. Bedenle ruh, insanla toplum arasında analojiler kuran Platon açısından adalet erdemi, bireysel ve toplumsal mutluluğu sağlama noktasında kilit konumdadır. Ona göre yalnızca adil bir ruh mutluluğa erişebilir ve ancak adil toplumlar mutluluğa kavuşabilirler.

Felsefe tarihinin en önemli isimlerinden biri olan Platon, hayatın ve dola- 
yısıyla felsefenin en önemli sorunlarını konu edinen çalışmalar yaptığı için güncelliğini hâlâ korumaktadır. Eserleri, yaşanan gelişmelere bağlı olarak tekrar tekrar okunmakta ve farklı bağlamlarda yeniden yorumlanmaktadır. Onun siyaset ve ahlaka ilişkin düşünceleri de günümüz dünyasında yankı bulmaya devam etmektedir. Bu nedenle adalet konusu da dahil olmak üzere literatürde Platon felsefesine ilişkin pek çok çalışma yapılmıştır ve yapılmaya devam edilmektedir. Platon üzerine yapılan bu kıymetli çalışmaların bazıları onun yalnızca adalet ya da yalnızca yasa veya düzen ile ilgili görüşlerine odaklanmıştır. Bazı çalışmalar ise Platon'un adalet anlayışı ile başka filozofların adalet anlayışlarını karşılaştırmaya yönelik hazırlanmıştır. ${ }^{1}$ Bu çalışma ise Platon'un adalet ile düzen, yasa ve ilgili diğer kavramlar arasında kurduğu ilişkileri göstererek literatüre katkıda bulunma amacı taşımaktadır. Genel olarak bakıldığında Platon düşüncesinde adaletin bireysel ve toplumsal bir erdem olarak tezahür ettiği ve onun düzen, mutluluk, yasa ve ceza konularıyla doğrudan ilişkili olduğu, bir kavram olarak tek başına ele alınmakla beraber bir kavram ağı içinde değerlendirilmesinin de mümkün olduğu görülmektedir. Bu nedenle Platon açısından adaletin ne olduğu sorusuna cevap aranırken, adalet kavramı bağlamında yasanın anlamı da ortaya konmuş ve aklın, yasanın, cezanın, eğitimin bireysel ve toplumsal adaleti sağlama noktasında oynadıkları rol açı̆̆a çıarılmaya çalışılmıştır.

\section{Platon'da Adaletin Değeri ve Onun ne Olmadığı}

Devlet diyalogunun ilk iki kitabında adalet ve adaletsizliğin ne olduğu, adil ve adil olmayan insanların kimler olduğu meselelerine dikkatli bir şekilde bakıldığında bu kavramların siyasal-toplumsal içerikli olmakla beraber bunların daha çok ahlaki kavramlar olarak ele alındıkları görülmektedir. ${ }^{2}$ Aslında bu durum Platon açısından oldukça anlaşılırdır. Çünkü Platon'un belki de en önemli eseri olan Devlet, diğer konuların yanı sıra "kişinin yaşamını iyi

İlgili bazı Türkçe çalışmalar için bk. Arslan Topakkaya, “Adalet Kavramı Bağlamında Aristoteles-Platon Karşılaştırması", FLSF (Felsefe ve Sosyal Bilimler Dergisi) 6 (2008), 27-49; Tuncay Ceylan, "Siyaset Felsefesinin Temel Problemlerinden Biri ve Birlikte Yaşamanın Koşulu olan Adalet (Platon)", Atatürk Üniversitesi Kazım Karabekir Eğitim Fakültesi Dergisi 14 (2006), 159176; Özgüç Orhan, “Homeros ve Hesiodos'da Adalet Kavramının Kökenleri ve Platon'a Yansımaları", FLSF (Felsefe ve Sosyal Bilimler Dergisi) 13 (2012), 11-38; Ayşe Gül Çıvgın, "Platon'un Adalet ve Filozof Kral Anlayışı", Insan ve Toplum Bilimleri Dergisi 7/1 (2018), 212-229; Ata Demir, Platon'da Adalet Kavraminin Temellendirilmesi (İstanbul: Marmara Üniversitesi, Sosyal Bilimler Enstitüsü, Yüksek Lisans Tezi, 2006); Yüksel Şengül, Platon ve Fârâbî'de Adalet Kavramı (Mardin, Mardin Artuklu Üniversitesi, Sosyal Bilimler Enstitüsü, Yüksek Lisans Tezi, 2017); Serdar Uslu, Platon'da Düzen Sorunu (İstanbul, İstanbul Üniversitesi, Sosyal Bilimler Enstitüsü, Doktora Tezi, 2007); Osman İnan Şenses, Platon'dan Smith'e Sosyal Düzenin İnşası (Ankara, Hacettepe Üniversitesi, Sosyal Bilimler Enstitüsü, Doktora Tezi, 2017).

2 Ahmet Arslan, İlkçă̆ Felsefe Tarihi 2 (İstanbul: İstanbul Bilgi Üniversitesi Yayınevi, 2018), 399. 
bir biçimde sürdürmesi yalnızca psişik uyumun sağlanmasıyla olur" tezinin, yani adaletin ayrıntılı bir şekilde açılanmasını içermektedir. ${ }^{3}$

Platon, Devlet adlı eserinde adaleti ağırlıklı olarak bireysel ahlak bağlamında ele alsa da onu siyasi açıdan değerlendirmekten de geri durmamıştır. $\mathrm{Bu}$, Antik Yunan felsefesi göz önüne alındığında anlaşılır bir durumdur. Eduard Zeller'in de belirttiği üzere Grek dünyasında ahlakla siyaset birbiriyle yakından ilişkilidir. Polis ayakta kaldığı sürece bireyi toplumdan ayrı düşünmek neredeyse imkânsızdır. ${ }^{4}$ Bu çerçevede Platon, adaleti bireyin ve toplumun manevi ve fiziksel ihtiyaçlarının doğru şekilde düzenlenmesi olarak tanımlayarak ikisi için ortak bir tanım getirmiştir. Devlet adlı eserinde bireysel adalete ağırlık veren Platon, Yasalar isimli kitabında siyasal ve toplumsal adalete vurgu yapmıştır. Yasalar'da adaletle ilgili Grekçe bir kavram olan nemesein fiili çok anlamlı bir şekilde geçer. Nemesein fiili, herkese kendi payını verme sorumluluğunu taşıyan kozmik tanrıçanın intikamını dile getiren he nemesis sözcüğüyle ilişkilidir. Bu tanrıça aşırı mutluluğu ve dünyanın paylaşımını altüst eden aşırı gururu cezalandırır. Nemesis'in öfkesi yasaların çiğnenmesinden doğar. Yunan dilinin nomos'u ile yasa ve yasaları çiğneyenlerin tavırlarına karşı "öfkelenen" nemesein "paylaşım tanrıçası" Nemesis kavramları arasındaki ilişki son derece anlaşılırdır. Yasalar'da belirtildiği üzere adaletin sözcüsü Nemesis, insanların sözlerini denetleme ve onların ölçüsüzlüklerini cezalandırma gücüne sahiptir. Yasalar'ın dördüncü bölümünde "Var olan her şeyin başını, ortasını ve sonunu elinde tutan yüce tanrının, evrenin gelişmelerini uygun biçimde düzenlediği" söylenir ve ardından "Tanrı yasalarından sapanları cezalandırarak intikam alan adaletin geldiği” ' belirtilir. Bu ifadelerden anlaşıldığı üzere yasaları çiğneyen kişi sadece insanlara karşı değil, aynı zamanda tanrılara karşı da saygısızlık etmiş olur. Çünkü o, bu eylemiyle evrenin düzenini bozmuştur. Yeryüzünün ve gökyüzünün yasalarını ve paylaşımını bildiren Nomos'a insanların aşırılıkları karşısında gazaba gelen adalet eklenir. ${ }^{5}$ Platon, adalet temsilcisi Nemesis'in ölçüsüz her eylemi uygun şekilde cezalandırma gücüne sahip olduğunu belirtir. ${ }^{6}$ Anlaşıldığ 1 üzere Platon için adaletin tanr1sal bir yönü vardır. Adalet kozmik bir anlama sahiptir ve evrendeki düzenin korunmasıyla ilgilidir. Ancak bu anlayış, olgular ve değerler arasında keskin

3 Joshua I. Weinstein, "Platon'un Devlet'inde Adalet Mutluluk Getirir", çev. Mustafa Topal, Batı Felsefesindeki 100 Temel Mesele, ed. Kıvanç Koçak (İstanbul: İletişim Yayınları, 2014), 294.

4 Eduard Zeller, Grek Felsefesi Tarihi, çev. Ahmet Aydoğan (İstanbul: Say Yayınları, 2008), 212.

5 Jean-François Mattei, Platon, çev. İsmail Yerguz (Ankara: Dost Kitabevi, 2008), 26.

6 A.g.e., 87. 
bir ayrım yapan ve kendi başına evrenin herhangi bir değere sahip olmadı̆̆ını düşünen modern dünya için kabul edilebilir bir görüş değildir.

Paton’a göre adalet, tanrısal bir değere sahiptir ve tanrılarla yakından bağlantılıdır. Bir yanda paylaşım tanrıçası Nemesis yasalara uymayarak adaletsizlik yapanları cezalandırırken, diğer yanda adalete büyük saygı besleyen insanlara yoldaşlık eden tanrılar vardır. Platon'a göre bu tanrıların başında insanların eylemlerindeki hakka aykırılıkları veya uygunlukları denetlemeye gelen yabancılar tanrısı yer alır. ${ }^{7}$ Tanrıların adaletle ilişkisi bakımından söylenmesi gereken şeylerden biri de adaletin tanrıların üstünde yer alan bir ilke olduğudur. Platon'a göre her tanrı bütünün düzenine bağlı olarak hareket eder; bu, adalet ilkesidir (dike). ${ }^{8}$ Günümüzde ise seküler zihniyetin hakimiyeti nedeniyle adalet mefhumu tanrı veya tanrısallıkla ilişkili olarak düşünülmemektedir. Adalet, bütünüyle insani bir mesele olarak ele alınmaktadır.

Platon'a göre insanlar ve evren için çok önemli olan adaletin ne olduğunu tam olarak ortaya koymak kolay bir iş değildir. Platon'un felsefi soruşturma ile bilgisine ulaşmak istediği şey, bir eylem ya da eylemler sınıfı hakkında bizi onu adil diye nitelendirmeye yönelten şeyin ne olduğudur. $\mathrm{O}$, bir adil eylemler listesi değil, böyle bir listeye dahil olmak veya böyle bir listenin dişında tutulmak için kullanılacak bir kriter elde etmek ister. ${ }^{9} \mathrm{Bu}$ onun bilgi anlayışına uygun bir tavırdır. Platon, bilgi söz konusu olduğunda şehrin haline değil şehrin kendisine, adil ya da adaletsiz bir fiile değil, bizzat adaletin kendisine, asil davranışlara değil, asilliğin kendisine dikkat kesilmemizi ister. ${ }^{10}$

Platon, adalet kavramını tanımlama çabası içerisinde bazı adalet tanımlarını tartışır ve bunları reddeder. Bu tanımlardan en dikkat çekici olanı Thrasymachus'un adalet tanımıdır. Thrasymachus, "adalet"in bencillikten başka bir şey olmadığında ısrarlıdır. Ona göre güç kimin elindeyse, kanunlar da o el tarafından kendi amaç ve çıkarları doğrultusunda yapılır. Bu açıdan adalet, yönetenin işine gelendir ve güçlünün iradesinin tezahüründen başka bir şey değildir. ${ }^{11}$ Dünyada yalnızca bir tek yasa vardır, o da özçıkar yasasıdır. Adalet özçıkarı kontrol eden ahlaki bir yasa değildir. Aksine, öçzıkar arayışını

Platon, Sofist, çev. Cenap Karakaya (İstanbul: Sosyal Yayınlar, 2000), 216b.

Jean-François Mattei, Platon, 36.

Alasdair MacIntyre, Homerik Çă̆dan Yirminci Yüzyıla Ethik'in Kısa Tarihi, çev. Hakkı Hünler Solmaz Zelyüt Hünler (İstanbul: Paradigma Yayınları, 2001), 41.

10 Eric Alfred Havelock, Platon/Filozof Şaire Karşı, çev. Adem Beyaz (İstanbul: Pinhan Yayıncılık, 2015), 220.

11 Platon, Devlet, çev. Sabahattin Eyüboğlu, M. Ali Cingöz (İstanbul: İş Bankası Kültür Yayınları, 2005), 336c-d. 
meşrulaştırmak için tasarlanmış süslü bir giysi, bir kamuflajdır. Güçlülerin salt zorbalıkla yönetmeleri mümkünse de uygarlığın gelişiminin bir noktasında güç, kitlelerin gözünü korkutmanın en iyi yolunun, onları "adalet"e boyun eğdirdiklerine inandırmaktan geçtiğini anlayan kişilerin eline geçmiştir. $\mathrm{O}$ tarihten itibaren güçlüler, kendi işlerine yarayan şeyleri yasa ve kural haline getirebilmek için buna adalet demişlerdir. Ancak esas itibarılyla bu, sahtekârca bir oyundur. Yönetilenlerin, yöneticilerin özçıkarlarını sağlamalarına sessizce rıza göstermelerini sağlayan etkili bir yoldur. ${ }^{12}$

Thrasymachus'un iddialarına benzer görüşler Glaukon tarafından da ileri sürülür. Ona göre bir doğa durumu içindeki insanlar bütünüyle özçıkar tarafından yönlendirilirler. Yasaların kökeninde insanların, özçıkar çatışmalarının çok zararlı olduğunu, başkalarına kötülük yapmaktan vazgeçmenin, başkalarının kendilerine yapacağı kötülük tehlikesini göze alarak onu devam ettirmekten daha fazla çıkarlarına uygun olduğunu keşfetmeleri bulunur. İnsanların yasaya itaat etmesinin nedeni de itaat etmemenin doğuracağı olumsuz sonuçlardır. Şayet insanlar eylemlerinin kötü sonuçlarından kurtulabilecek olsalardı yasaya bağlı kalmazlardı. Yani başarılı bir şekilde adaletsiz olabilseydiler, adaletsizliği adalete tercih ederlerdi. ${ }^{13}$ Adaletin konumunu keyfi bir hale sokan, Hobbes'un insan doğası ve devlete ilişkin düşüncelerini anımsatan bu görüşlere karşın Platon'a göre insan hayatının anlam kazanabilmesi, insanın gökyüzü ve yeryüzü, insanlar ve tanrılar arasında bulunan yasalara saygılı olması ve her şeyi adil bir dağılım içinde birleştiren bağı bulabilmesi ile mümkündür. ${ }^{14}$ Her şeyin ölçütünün insan olduğunu söyleyen Protogoras'a karşılık, her şeyin ölçütünün Tanrılar olduğunu ileri süren Platon'un, adaleti insanların öznel nitelikteki özçıkarlarına indirgeyen bu yaklaşımı benimsemesi beklenemez. Bu nedenle Platon açısından Thrasmachus'un ve diğerlerinin adalete ilişkin bu iddiaları hiçbir şekilde kabul edilebilir değildir. Adalet, güçlü olanın üstü örtük şekilde özçıkarını gerçekleştirmesi olamayacağı gibi özçıkar korkusuyla benimsenen bir araçtan ibaret de değildir. Tanrısal bir kökeni olan, hatta tanrılar üstü bir konumda olan adalet, insanın onu tanımasıyla diğer yaratıklardan ayrıldığı önemli bir değerdir. Platon, bu iddiasını "İnsan da öteki hayvanlardan daha anlayışlı olduğu gibi, din ve adalet tanıyan biricik yaratı̆̆ıdır." sözüyle dile getirir. ${ }^{15}$

12 Jeffrey Abramson, Minevra'nın Baykuşu/Batı Siyasi Düşünce Tarihi, çev. İbrahim Yıldız (İstanbul: Dipnot Yayınları, 2014), 36-37.

13 Platon, Devlet, 359a-b.

14 Jean-François Mattei, Platon, 87.

15 Platon, Meneksenos, çev. İrfan Şahinbaş (İstanbul: Sosyal Yayınlar, 2001), 237d. 
Adaletin kişiler arası çıkar çatışmalarını önleyerek kişisel çıkarın korunmasına hizmet ettiği doğrudur fakat Platon, adaletin kişisel çıar bağlamında ele alınmasına ve özçıkarın korunmasını sağlayan bir araca indirgenmesine karşı çıkar. Öyle ki o, kişisel hazların yeri geldiğinde adalet uğruna bir kenara bırakılması gerektiği düşüncesindedir. Platon'a göre filozof kral, dünyada bulabileceği mutluluğu bulmuş olsa ve devlet işlerine karışmak istemese de halkı adaletle yönetmek için devletin başına geçmeli, aslında bir tür fedakârlıkta bulunmalıdır. ${ }^{16}$ Dolayısıyla adalet özçıkarın korunmasını sağlayan bir araçtan ibaret olmadığı gibi yeri geldiğinde özçıkarın feda edilmesini de gerektirebilmektedir.

Platon'a göre adalet, diğer idealar gibi gerçek bir varlığa sahiptir. Güzel, iyi ve adalet idealarının idealar âleminde gerçekten var olduğunu düşünen Platon'a göre bu maddi dünyada adalet, adalet iddiasından pay aldığı ölçüde somutluk kazanmaktadır. Platon için yaşadığımız adaletsizliklere rağmen insanların adalete yönelme ve onu arzulama nedeni de bu adalet ideasıdır. İçinde bulunduğumuz bu dünyada kusursuz ve mükemmel bir adalet örneği olmamasına rağmen insanların adalet hakkında konuşabilmesi, farklı adalet anlayışlarını karşılaştırabilmesi ve adalete ilişkin çeşitli uygulamaları eleştirebilmesi idealar âlemindeki adalet ideası ile mümkün olmaktadır. ${ }^{17}$

Adalet, idealar âleminde bulunan bir ideadır ve bu dünyada mükemmel biçimde tezahür edememektedir. Bu nedenle bu maddi dünyada adalet asla tam olarak gerçekleşmeyecektir. Buna rağmen adalet ideasının bilgisine erişmek ve hakkında bir kuram oluşturarak yeryüzü dünyasında mümkün olduğu kadar adil bir düzen oluşturmak mümkündür. Adalet ideası, insanlara bu dünyadaki adaletsizlikleri tanıyıp bunları düzeltme imkânı sağlar. Ancak bunun olabilmesi için hem adalet ideasının bilgisini sağlayacak bir bilgelik hem de bu bilgiye uygun düzenlemeler yapabilecek siyasi bir güç gerekir.

\section{Ruh ile Devlet Arasında Kurulan Benzerlik}

Platon için adalet, en genel anlamıla bireyin ve devletin işlevini, iyisini, üstünlük ve faziletlerini uyumlu bir şekilde gerçekleştirmesidir. Bireyin bu uyumu yakalayabilmesinin tek yolu, ruhun iştah, öfke gücü ve akıl olarak ayrılan kısımlarından akla göre hareket etmesidir. Polis'in mutlu bir insan topluluğu olabilmesi, yani adil olabilmesi ise bireylerin, ruhlarının akılsal kısmına göre yaşaması ve akla göre hükmeden insanların yönetici olması ile

16 Platon, Devlet, 520a.

17 Yurdagül K. Adanalı, “Düzen mi Anarşi mi?", Felsefeye Giriş/Temel Problemlere Sistematik Yaklaşım, ed. Murat Arıcı (Ankara: Nobel Akademik Yayıncılık, 2019), 239. 
mümkündür. Diğer yandan ideal bir devlette uyumlu bir işbirliği hüküm sürer ve bu uyumlu iş birliği her bireyin kendi doğasına uygun işlevleri yerine getirmesine bağlıdır. ${ }^{18}$

Platon'un bireyin ve devletin adaletine ilişkin görüşlerini en kısa şekilde yukarıdaki gibi özetlemek mümkündür. Burada öne çıkan temel görüşler, hem ruhun hem de devletin kısımlardan oluştuğu ve bu kısımların kendilerine uygun birer doğaya ve işleve sahip olduğu, adaletin ancak bu işlevler doğaya uyumlu bir birliktelik içinde yerine getirildiğinde ortaya çıkacağ 1 şeklindeki düşüncelerdir. Görüldüğü gibi bu düşünceler, insan ruhunun kısımları ile insanlardan müteşekkil devletlerdeki toplumsal sınıflar arasında doğa ve işlevler bakımından benzerlikler olduğunu varsayar ve bu nedenle insan ruhu ile devlet arasında bir analoji kurar. Platon'a göre adaletin doğasının ne olduğunu tespit etmek güç bir iş olduğu için bu benzerlikten yola çıkarak adalete daha büyük ölçekten, adil şehirden bakılmalıdır. Çünkü Platon'a göre adalet tek bir insanda bulunduğu gibi bütün bir insan topluluğunda da mevcuttur ve adalet, daha büyük olan şeyde daha büyük ölçüde bulunduğu için onu orada görmek daha kolaydır. ${ }^{19}$

Aslında Platon'un siyaset konusundaki görüşlerinde yalnızca ruh ile devlet arasında bir benzerlik kurulmaz. Çeşitli şeyler arasında kurulan benzerliklerin sayısı birden çoktur. Hatırlanacağ 1 üzere o, evren, site ve insan arasında da bir analoji kurmuştur. Platon'a göre düzenli bütün anlamına gelen kozmos, siteyi ve insanı içine alır; ayrıca sitenin ve insanın nasıl olması gerektiğine ilişkin ana planı sunar. Başka bir deyişle düzenli bütün ya da doğal evren anlamına gelen kozmos, politik evrenle bireysel insani evrenin kendisine göre düzenleneceği şablonu temsil etmektedir. ${ }^{20}$ Bilindiği üzere Platon yalnızca insanı değil, evreni de canlı bir organizma olarak görür. ${ }^{21}$ Evrendeki düzenin bir benzerinin sitede ve kişinin ruhunda teşekkül etmesini adalet ve mutluluk için zaruri gören Platon, bireyin ruhunda ve sitede bu düzenin nasıl kazabileceğini açıklamaya girişir.

$\mathrm{Bu}$ açılamaya göre ruhun üç kısmına ve toplumsal üç sınıfın her birine uygun düşen birer erdem vardır. Toplumu oluşturan yönetici, koruyucu ve besleyici kesimler ruhun üç yanına karşlık gelirler. Bu sınıflardan ilki bilgeliğiyle, ikincisi yiğitliği ve eğitilmiş gücüyle, üçüncüsü de toplumun bedensel

18 Barış Mutlu, “Platon'un Devlet'inde Filozofun/Filozofların Kral Olması Adil midir?”, Özne 24 (2016), 146.

19 Platon, Devlet, 368e-369a.

20 Ahmet Arslan, Ilkçă̆ Felsefe Tarihi 2, 396.

21 Platon, Timaios, çev. Erol Güney - Lütfi Ay (İstanbul, Sosyal Yayınlar, 2001), 30a. 
ihtiyaçlarını karşılayarak topluma hizmet eder. Devlet, kurum ve yasaları yöneticilerin bilgeliği ile biçimlendiğinde, askerlerin kahramanlığı ile korunduğunda, bu yasalara ve kurumlara üretici sınıf tarafından sadakatle itaat edildiğinde düzenli ve adil bir devlet olur. ${ }^{22}$ Adalet, bireysel anlamda ruhun her kısmının görevini eksiksiz bir şekilde yerine getirerek kendisine uygun düşen erdemi elde etmesinden ibarettir. Bu açıdan adalet, ruhtaki egemen ve bağımlı unsurlar arasında hiyerarşik bir düzen kurulmasını gerektirir. Bu hiyerarşik düzenin bir benzerinin de sitede oluşturulmasıyla siyasi anlamda adalet ortaya çıkar. Bu çerçevede adaletsizlik de ruhta ya da siyasi alanda yöneten ve tabi olan kısımlar arasındaki hiyerarşik düzenin bozulmasıdır.

Platon için site ile birey arasındaki ilişki basit bir analoji olmanın ötesindedir. Platon, bireyin kişisel yazgısı ile toplumun kaderi arasında sıkı bir bağ kurar. Bireyler devlete şekil verirken, devlet de bireyleri biçimlendirir. Bu nedenle birey içinde yaşadığ ${ }_{1}$ devletin mizacını taşır. ${ }^{23}$ Platon'un ifadesi ile "devlet nasıl doğru olursa, insan da o türlü doğru olur." ${ }^{24}$ Devlet akıllı usluysa birey de akıllı uslu olur. Devlet ve birey arasındaki karşıllıklı ilişkinin neticesi olarak devlet, bireylerin yaptıkları şeyken, bireyler de devletlerin onlara yaptığı şey olmaktadır. ${ }^{25}$

\section{Bireysel Bir Erdem Olarak Adalet}

Adalet ve mutluluk arasında doğrudan bir ilişki kuran Platon'un, Devlet adlı eserindeki temel iddiası, adaletin mutluluk, başarı ve hoşnutluğun birlikteliğinden oluşan eudaimonia' yı sağlayan mükemmellik ya da erdem (aretê) olduğudur. ${ }^{26}$ Burada başarıdan kasıt, kişinin iyi bir işlev görmesi, üstlendiği işleri iyi yapması ve girişimlerinde neticeye ulaşmasıdır. Hoşnutluk ise duyulan memnuniyettir. ${ }^{27}$ Mutluluk Platon'a göre ruhun bölümleri arasındaki uyum ile bağlantılıdır ve bu uyumun sağlanması aklın yol göstericiliğini gerektirmektedir. ${ }^{28}$ Ruhun bölümleri arasındaki uyum ise adaletin bireysel

${ }_{22}$ Alfred Edward Taylor, Platon/Bilgi, Ruh ve Devlet, çev. Cengiz İskender Özkan (Ankara: Fol Kitap, 2020), 80-81.

23 Ebamüslim Akdemir, İnsan Felsefesi/Epiktetos ve Marcus Aurelius Örneği, (İstanbul: Birey Yayincilik, 2010), 79.

24 Platon, Devlet, 441d.

25 Jean Brun, Platon ve Akademia, çev. İsmail Yerguz (Ankara: Dost Kitabevi, 2007), 112.

26 Joshua I. Weinstein, "Platon'un Devlet'inde Adalet Mutluluk Getirir", 290.

27 Raymond Geuss, Sokrates'ten Adorno'ya Felsefe, çev. İbrahim Yıldız (İstanbul: Dipnot Yayınlar1, 2019), 71.

28 Celal A. Kanat, Platon ve Aristoteles'te Devlet ve Toplum Felsefesi (İstanbul: Doruk Yayımcilık, 2013), 86. 
bir erdem olarak gerçekleşmesi ile sağlanır. Bunun anlamı, adalet olmaksızın mutluluğun mümkün olmadığıdır.

Platon, bu konuda analoji yoluna başvurur ve beden ile ruh arasinda benzerlik kurar. Önce bedenden bahseden Platon, sağlığı, bütün organların bireyin hayatında genel bir birliktelik içinde kendi etkinliklerini gerçekleştirmeleri olarak tanımlar. Sağlığa benzer şekilde eudaimonia da ruhtaki her bir parçanın kendi yerini bilerek uygun düştüğü görevi yerine getirmesidir. Bunun sonucu olarak ortaya çıan adalet, psikolojik ahengi yaratır ve onu korur. Böylece insan varlığının iyiliği olan mutluluk ortaya çıkar. ${ }^{29}$

Platon'a göre ruh, ne sadece farklılaşmamış bir birlik ne de bağımsız ve bağlantısız etkinlikler çokluğudur. Farklı etkinlikler yığını olmayan ruh, fark1 işlevlerin, bir başka deyişle parçaların ya da türlerin bir çokluğunun fark edilebileceği bir birliktir. Bu parçalar ya da türler sayı olarak üçtür. Bunlar: (i) Akıl yürüten kısım, (ii) iştah duyan kısım, (iii), öfkelenen kısım. ${ }^{30}$ Ruhu oluşturan bu farklı kısımlar nedeniyle her insanda çatışan dürtüler ve yetenekler mevcuttur. İnsan yalnızca bu dürtü ve yeteneklere hükmederek ve onları bütünleştirerek kendisiyle barışık biri haline gelebilir. İnsandaki içsel çatışmaların, sahip olduğu her kısmın yapması gerekeni yapması ve diğer kısımların işine karışmaması ilkesine göre çözülmesi gerekir. Neyin yapılıp neyin yapılmayacağına karar vermek ise aklın görevidir. ${ }^{31}$ Düzenli ve uyumlu bir ruhun iyiliğinden kuşku duymayan Platon, ruhtaki her şeyin düzene sokulması ve her bir parçasının öteki parça ile uyumlu kılınması gerektiğini söyler. ${ }^{32}$ Ruhunda uyumu ve düzeni yakalayan kişi adil bir insandır. Platon, adilliği kendi içinde taşıyan, ona sahip olan ruha adaletli der ve bunun aksine adaletsizliğe sahip olan ruha da adaletsiz der. ${ }^{33}$ Platon'un adalet anlayışına göre bireysel bir erdem olarak adalet, içsel bir durumdur ve ruhun hiyerarşik yapısının işlevlerini uyumlu bir şekilde yürütmesinin bir sonucu olarak ortaya çıkar. Adil bir insan, adalet erdeminin yanı sıra ruhunun her kısmı kendi işlevini yerine getirdiği için diğer erdemlere de sahiptir. İştahasında ölçülülük, öfke gücünde cesaret ve aklında bilgelik erdemleri tezahür eder. Adil bir insanın ruhunda yönetici, akıldır. Bu çerçevede Platon, ister haksızlığa yol açsın ister açmasın öfkenin, korkunun, hazzın, acının, kıskançlıkların ve

\footnotetext{
Ahmet Cevizci, Etik/Ahlak Felsefesi (İstanbul, Say Yayınları, 2018), 162.

Taylor, Platon/Bilgi, Ruh ve Devlet, 65-66.

Joshua I. Weinstein, “Platon'un Devlet'inde Adalet Mutluluk Getirir”, 292.

32 Platon, "Gorgias", Diyaloglar, çev. Melih Cevdet Anday (İstanbul: Remzi Kitabevi, 2009), 503e.

33 Platon, Sofist, 247a.
} 
tutkunun ruhtaki egemenliğine "adaletsizlik" der. ${ }^{34}$ Ona göre adaletsiz insan kötü bir insandır. ${ }^{35}$

\section{Siyasi Bir Erdem Olarak Adalet}

Adil kişinin ruhunda, akli olmayan kısımlar akla tabi olduğu gibi ölçülü ve kendine hâkim bir devlette de iyi yan kötü yanı buyruğu altına alır. ${ }^{36}$ Platon, toplumun farklı kesimlerini nitelik açısından değerlendirmekte ve insan ruhunda olduğu gibi toplumda da bir hiyerarşi oluşturmaktadır. Akıl, ruhun diğer kısımlarına üstün olduğu gibi toplumu yönetmesi gereken filozof krallar da toplumun diğer kesimlerinden üstündür. Bunun anlamı, eğitim görmüş aklın iyi düzenlenmiş bir toplumda kamusal hayatın gidişatını belirlemesi gerektiğidir. ${ }^{37}$ İyi düzenlenmiş adil bir devlet yönetilirken bilgelik, savunulurken cesaret, tüm yönetim düzeni onaylanırken de ölçülülük erdemi ortaya çıkar. ${ }^{38}$ Böylece ideal site düzeni dört temel erdemi bir araya getirir.

Platon, toplum düzeninin tesisini, insanların birbirinin eksiğini tamamlayabilmesi ile açıklar. Ona göre birçok eksik, birçok insanın bir araya gelmesine yol açar. İnsanlar bu şekilde yardımlaşarak bir ortaklık içinde yaşarlar. ${ }^{39}$ İnsanların yaşamsal ihtiyaçları iş bölümüne yol açar. Böylece site kurulduğu andan itibaren kapasiteleri, eğilimleri ve işlevleri farklı ve eşitsiz insanlardan oluşur. Site büyüdükçe toplumsal ihtiyaçlar ve işlevler de artarak karmaşıklaşır. Bu nedenle beslenme ve barınma gibi ihtiyaçları karşılayan zanaatkârlar yeterli gelmez ve sonunda site askerlere ve kendisini yönetecek kimselere sahip olmak zorunda kalır. Bu üç sınıf, üretim, savunma ve yönetim işlevlerini yerine getirir. ${ }^{40}$ Platon, toplumları yerine getirdikleri işler açısından sınıflara ayırırken bu sınıflardan biri olan zanaatçıları skholê'den, yani felsefi spekülasyon veya şehrin idaresine katılmalarını sağlayan boş vakitten mahrum bırakir. ${ }^{41}$

Platon'a göre kişinin toplum içerisinde yerine getireceği işi belirleyen şey,

34 Platon, Yasalar, çev. Candan Şentuna - Saffet Babür (İstanbul: Kabalcı Yayınevi, 2007), 863e864a.

35 A.g.e., $860 \mathrm{~d}$.

36 Platon, Devlet, 431a.

37 Taylor, Platon/Bilgi, Ruh ve Devlet, 20-21.

38 Martin Cohen, Platon'dan Mao'ya Siyaset Felsefesi, çev. Hamdi Bravo (Ankara: Fol Kitap, 2020), 41.

39 Platon, Devlet, 369b-c.

40 Brun, Platon ve Akademia, 111.

${ }^{41}$ Jeremy F. Lane, "Ranciére' in Anti-Platonculuğu: Eşitlik, "Yetim Mektup" ve Sosyal Bilimlerin Sorunsalı, çev. Erdem Baykal, Yaşayan Platon/Çağdaş Fransız Felsefesinde Platon Okumaları, ed. Sadık Erol Er - Birdal Akar (Konya: Çizgi Kitabevi, 2017), 243-244. 
kısmen o kişinin erken çağlardaki eğitimi olsa da temelde belirleyici olan unsur, o kişinin doğuştan sahip olduğu yeteneklerdir. Platon, doğuştan kunduracıların ve doğuştan yöneticilerin varlığına inanır. ${ }^{42}$ Ona göre herkes için en iyi şey, herkesin doğuştan yetenekli olduğu işi yapmasıdır. Görüldüğü üzere Platon, insanların birtakım işlere yatkın olarak doğduklarını söylemekte ve adaleti de onların yatkın oldukları bu işleri yerine getirmesiyle ilişkilendirmektedir. Aslında Platon'un, adaleti kendi işini gören ve başkasının işine karışmayan iş bölümünde bulması Antik Grek dünyasının zihniyetine uygun bir yaklaşımdır. Russell'ın belirttiğine göre felsefe ortaya çıkmadan önce Greklerin evren konusunda dinsel bir görüşleri vardı. Buna göre her insan, her şey belirli bir yere ve göreve sahiptir. Dinî görüşe göre bu durum kişisel olmayan, Olympos üstü bir yasaya dayanmaktadır. ${ }^{43}$

Platon, yurttaşların yeteneklerine uygun işler yapması gerektiğini söylerken liyakati vurgulamakta, buna karşın toplumsal rol değişimlerine sıcak bakmamaktadır. Onun adil devletinde kişilerin keyfi biçimde toplumsal rollerini değiştirme şansları olmadığı gibi böyle bir özgürlük talebinde de bulunamazlar. Çünkü yurttaşların temel kaygısı, kişisel tercihleri veya özçıkarları olmamalı, içinde yaşadıkları topluma en iyi şekilde hizmet etmek olmalıdır.

Platon için siyasi adaletin sağlanması açısından bakılması gereken unsur, doğuştan gelen yetenekler olmakla birlikte o, adil bir toplum için eğitimi de gerekli görür. Devlet tarafından verilecek ve kişinin doğasına uygun olacak bir eğitim, herkesin doğal iyiliğini biçimlendirecektir. ${ }^{44}$ Bu nedenle adil bir toplumun teşekkülü için eğitim şarttır. Bu çerçevede Platon için devletin temel sorunu, yurttaşların erdemli olacak şekilde nasıl eğitileceğidir. Platon, bu sorunu çözmek için toplumun özellikle koruyucular ve yöneticiler sınıfına yönelik bir eğitim programı belirlemiştir. ${ }^{45}$ Çünkü hükümdarlık için gereken donanım öncelikle bilim ve felsefenin ilkelerinin bir bütün olarak öğrenilmesiyle kazanılabilir. Bu donanım yüzeysel bir eğitimle elde edilemez. ${ }^{46}$

Toplumu yönetecek kimseler için iyi bir eğitimi gerekli gören Platon, adaleti sağlamaları açısından bu eğitimi yeterli bulmaz. Devlet adlı eserinde yöneticilerin her şeyden çok sitelerine bağlı kalmalarını ve ona hizmet etmelerini

\footnotetext{
MacIntyre, Homerik Çă̆dan Yirminci Yüzyıla Ethik'in Kısa Tarihi, 48.

43 Bertrand Russell, Batı Felsefesi Tarihi I, çev. Muammer Sencer, ( İstanbul: Say Yayınları, 2002), 244-245.

44 Alain Badiou, Platon'un Devleti, çev. Savaş Kılıç - Nihan Özyıldırım (İstanbul: Metis Yayınları, 2015), 150.

45 Veli Urhan, "Platon'un Siyaset Felsefesinde İdeal Devlet", Özne 24 (2016), 199.

46 Taylor, Platon/Bilgi, Ruh ve Devlet, 22.
} 
sağlamak için özel mülkiyeti ve aileyi ortadan kaldırmayı önerir. Her yurttaş için geçerli olmayan, sadece yöneticiler ve koruyucular için geçerli olacak bazı yasaklar öngören Platon, onlara özel mülkiyeti, evliliği ve aile kurmayı yasaklar. ${ }^{47}$ Hiçbir kişisel ilgi, onların halkın bütünü için duydukları ilginin önüne geçmemelidir. Bu haklardan mahrum olan yöneticiler, toplumun diğer kesimlerinden farklı olarak devleti yönetme hakkına sahip olurlar. Ancak Platon daha sonra Yasalar adlı kitabında herkese otuzuyla otuz beşi arasında evlenme zorunluluğu getirerek bu fikrinden vazgeçmiştir. ${ }^{48}$

Çok az insanda aklın ve ruhun geri kalan kısımlarının kendi üzerine düşen işi yaparak adil olabildiğini söyleyen Platon açısından adil yöneticiler çok büyük bir önem taşırlar. Bireysel anlamda adalet sahibi olan bu kişiler yönetici oldukları takdirde devletin de adil olmasını sağlayacaktırlar. Bu nedenle Blackburn'ün söylediği gibi "Yönetici seçkinler toplumun mutluluğunun güvencesidir." demekte bir beis yoktur. ${ }^{49}$ Bu kişiler sahip oldukları adalet erdemini siyasi iktidar aracılığ ile toplumun geri kalanına yansıtacak, adil ve mutlu bir toplum tesis edecektirler. Platon'a göre gerekli erdemlere sahip kişiler kral ya da önder olmadıkça, yani devlet gücüyle akıl gücü aynı kişide birleşmedikçe, kesin bir kanunla herkese yalnızca kendi yapacağı iş verilmedikçe devletlerin başı beladan kurtulmayacaktır. Bu tür devletlerde ne tek tek bireyler ne de toplum mutluluğa kavuşabilir. ${ }^{50}$ Çünkü toplumu kurtaracak olanlar, akıl ile birlikte adalet ve ölçülülükken, onu yıkacak olan da adaletsizlik ve aşırılıktır. ${ }^{51}$ Toplumu kurtaracak olan akıl da filozof kralda bulunur.

Platon'un Devlet isimli eserini karakterize eden adalet tartı̧ması, yönetim biçimleri tartışmasında da merkezî bir rol oynar. Buna göre aristokratik ideal devletten her uzaklaşma aslında adaletten uzaklaşmadır. ${ }^{52}$ İdeal devlet düzeninden uzaklaşan devletler bu idealden adım adım, tedricen uzaklaşırlar. İlk ve en iyi düzeni monarşi ya da aristokrasi olarak gören Platon'a göre ideal rejim dahil olmak üzere toplamda olası beş siyasi rejim türü vardır. İlk ve en iyi düzen olan monarşi ya da aristokrasidir. İdeal düzenin dişında dört rejim türü daha vardır. Bunlar, sırasıyla timokrasi, oligarşi, demokrasi ve zor-

47 Platon, Devlet, 464a-c.

48 Platon, Yasalar, 721b.

49 Simon Blackburn, Devlet ve Platon, çev. Merve Yüksel - Müzeyyen Baturay (Ankara: Versus Kitap, 2014), 79.

50 Platon, Devlet, $473 \mathrm{~d}$.

51 Platon, Yasalar, 906b.

52 Hatice Nur Erkızan - A. Kadir Çüçen, Felsefe Tarihi I/Antik Çă̆ Ve Orta Çă̆ Felsefesi Tarihi (Ankara: Sentez Yayıncılık, 2013), 105. 
balıktır. ${ }^{53} \mathrm{Bu}$ rejimlerden her biri yıkılıp yerine bir sonraki geçecektir çünkü her aşırılığın ardından her zaman bir tepki gelir. ${ }^{54}$ Yöneticiler bilge kişiler olmaktan çıtığında aristokrasi, yerini barıştan çok savaş işlerine yarayan, kaba ve atılgan insanların beğenildiği timokrasiye bırakır. ${ }^{55}$ Yöneticiler, cesaret ve askeri becerilerini kaybettiklerinde timokrasinin yerini gelir üstünlüğüne dayanan oligarşi alır. ${ }^{56}$ Oligarşik devlette halk zengin ve fakir şeklinde ikiye bölünür. Halkın fakir kısmının zengin kısmı yenmesi ile de demokrasi ortaya çıkar. ${ }^{57}$ Demokrasi, en taşkın özgürlüklere imkân tanıdığ kölelik de oradan çıkacak ve demokrasi zorbalığın ortaya çıkacağı zemin olacaktır. ${ }^{58}$ Siyasi düzende yaşanan bu gelişmeler erdemlerle birebir ilişkilidir. Kenney'nin yorumuna göre ideal devlet düzeninden uzaklaşılan her adımda adaletten de uzaklaşılır ve adaletsizliğin hükümranlığının tam olarak tecessüm etmesi, demokrasiden despotizme geçilmesiyle olur. Aristokratik devlette bütün erdemler hep beraber bulunurken, timokratik devlet, bilgelikten yoksundur. Oligarşik devlette cesaret erdemi ortadan kalkmıştır. Demokratik devlette ölçülülük erdemi bulunmazken, despotik devlette adalet bütünüyle kaybolur. ${ }^{59}$

\section{Yasanın Anlamı ve Değeri}

Kamusal meselelere ve onları yürüten insanlara yön veren yasaların göreli önceliği, politik düşünce açısından hayli önemlidir. İyi yasalar ile iyi insanların bir araya gelmesinin çok iyi bir şey, kötü insanlar ile kötü yasaların birlikteliğinin de çok kötü bir şey olduğuna hiç kimse itiraz etmezken karışık durumlarda ne olacağı tartışmalıdır. Bazıları yasaların öncelikli olduğunu, iyi yasaların onları işletecek iyi insanların seçimini sağlayacağını söylerken, başkaları iyi insanların yetkili olması durumunda iyi yasalara duyulan ihtiyacın karşılanacağını ileri sürer. ${ }^{60} \mathrm{Bu}$ açıdan bakıldığında Platon'un hem yöneticinin nitelikleri hem de yasalar ve işlevleri üzerinde durduğu, bir şekilde ikisine de değindiği görülmektedir. Platon, yasaların önem ve gereğini belirtmekle beraber onların gücünün sınırlı olduğu görüşündedir. Çünkü yönetici

\footnotetext{
Platon, Devlet, 544e-545c.

A.g.e., 563e-564a.

A.g.e.,547e.

A.g.e.,550d-e.

A.g.e., 555b-557a.

A.g.e.,563e-5646.

Anthony Kenny, Batı Felsefesinin Yeni Tarihi I/Antik Felsefe, çev. Serdar Uslu (İstanbul: Küre Yayınlar1, 2018), 83.

60 Nicholas Rescher, 101 Anekdotta Felsefe Tarihine Yolculuk, çev. Abdullah Yılmaz (İstanbul: Vakıfbank Kültür Yayınları, 2019), 56-57.
} 
kötü olduğu takdirde iyi yasaların varlığı bile o kenti yıkımdan kurtaramaz. ${ }^{61}$ Ayrıca iyi yasaların bulunduğu bir devlette de suç işlenecektir, bu yüzden yasaların bir kısmının suçlar ve cezalarla ilgili olması gerekir. Tüm bunlar, yasaların iyi yönetimi sağlamada ve suçun önlenmesinde mutlak değil, sınırlı bir etkiye sahip olduklarını göstermektedir.

Platon, Devlet adlı eserinde daha ziyade yöneticinin kim olması ve ne tür özellikler taşıması gerektiği konusunu ele alırken, Yasalar'da devletin ne tür yasalar çıkarması gerektiği üzerinde durarak odak noktasına yasaları yerleştirir. Devlet'te yasalara ilişkin ayrıntılara girmeyen Platon, Yasalar'da kanunların amaçları ve doğrulukları konusuna değinir. Ona göre kanunların amacı iyilik, güzellik ve doğruluktur. Kanun koyarken bu konularda aldanmak, bir insanı yanlışlıkla öldürmekten çok daha büyük bir suçtur. ${ }^{62}$ Kanunların amacı, bazı yurttaşlara diğerlerinden üstün bir mutluluk sağlamak olmayıp, yurttaşları inandırarak ya da zorlayarak birleştirmek, her birine toplum içinde görebileceği iş payını aldırmak ve böylece bütün toplumu mutlu etmektir. ${ }^{63}$ İyinin, doğrunun ve güzelin birbirinden ayrı düşünülmediği Antik Grek dünyasının bir üyesi olan Platon da bunları bir ve aynı şey olarak görür. Bu çerçevede yasalar iyi, güzel ve doğru olmalıdırlar ki adalet sağlanabilsin. Toplumda liyakate dayalı bir iş bölümü gerçekleştiği takdirde, toplumun yalnızca bir kısmı değil, tamamı mutlu olabilecektir. Platon, ideal devlette toplumun tamamının mutlu olacağını söylerken, acının insan gerçekliğinin bir parçası olduğu hususunda uyarıda bulunmaktan geri duymaz. Adil bir devlette dahi tutkular, zevkler ve acılar olacaktır. Bunlar çocuklarda, kadınlarda, kölelerde ve hatta bütün değerlerine rağmen özgür insanlarda bile olacaktır. ${ }^{64}$ Platon'un ideal devleti ütopik karakterine rağmen gerçeklikten tümüyle uzak değildir. İnsanların ancak ideal bir devlette mutlu olabileceklerini iddia eden Platon, böyle bir devlette bile tutku, zevk ve acıların var olmaya devam edeceğini belirtir.

Platon, Yasalar adlı eserinde yasaları çeşitli yönleriyle ele alır. Bu çerçevede yasaların gerekliliğinden, kaynağından, niteliklerinden, içeriğinden, amaçlarından, cezaların amaç ve türlerinden bahseder. Platon, ruhun davranış düzenine, düzgünlüğ̈üne "yasalara uygunluk" veya "yasa" der. İnsanı yasalara uygun ve düzenli kılan da odur. İnsan yasa sayesinde ölçülü ve doğru olur. ${ }^{65}$ Platon'a göre yasalar insan kökenlidirler ve insan ruhundan kaynaklanırlar.

\footnotetext{
61 Platon, Yasalar, 751c.

62 Platon, Devlet, 451a.

63 Platon, Devlet, 519e-520a.

64 Platon, Devlet, 431a.

65 Platon, "Gorgias”, 504d.
} 
Yasa, aklın bir ürünüdür ve bir bakıma da doğa ile özdeştir. ${ }^{66}$ Bu nedenle yasa doğaldır ya da doğadan aşağı kalmaz çünkü akıl bütünüyle doğal bir yetidir. ${ }^{67}$

Platon, yasaların keyfilikten kaynaklanmadığını, tek başına hiç kimse adaletsizlik yapmadan yönetemeyeceği için yasaların konmasının bir gereklilik olduğunu ileri sürer. ${ }^{6}$ Genel olarak yasa koymanın bir gereklilik olduğunu düşünen Platon, işlenebilecek suçlar ile ilgili yasaların konmasını korkunç ve hiç hoş olmayan bir iş olarak nitelendirir. Tam bir adaletsizlikle işlenen cinayetler çoğunlukla kötü yönetilen, eğitim sistemi bozuk devletlerde işlenir fakat böyle suçlar hiç umulmayan ülkelerde de görülebilir. Bu konularda yasaların halka duyurulması, yurttaşların bu tür cinayetlerden kendi istekleriyle uzak durmalarını sağlayabilir. ${ }^{69}$ Platon, ideal devletin halkın bütününü mutlu edecek devlet olduğunu söylerken bu devlette bile hemen herkes için bazı acıların olacağını inkâr etmez. Benzer şekilde ona göre her ne kadar adaletsiz bir devlette korkunç suçlar daha büyük oranda işlenecekse de ideal devlet de suçların hiç işlenmeyeceği bir devlet değildir. Orada da görece daha düşük oranlarda da olsa suçlar işlenecektir. Bu nedenle ideal bir devlette de ceza yasaları olmalıdır. Platon'un bu görüşleri, onun insana dair güvensizliğini ve realizmini ortaya koymaktadır. İdeal devlette yaşasalar dahi insanlar kötülükten tam olarak kurtulamazlar. Orada bile kötülük yapanlar olacaktır.

Yasaların yapılması bir devlet için son derece önemlidir. Bir siyasi yönetimin düzenlenmesinde iki aşama vardır. Önce yöneticiler ve görevleri saptanır; bunların kaç kişi olacağı ve nasıl belirleneceği tespit edilir. Sonra da bu görevlerin her birine ne kadar ve hangi nitelikte yasa uygun düşüyorsa bu yasalar çıkarılır. Görüldüğü üzere yasalar, siyasi bir yönetimin oluşması için gereklidirler. Ancak bir diğer gereklilik, bu yasaların nitelikli yöneticiler eliyle yürütülmesidir. Platon'a göre yasama önemli bir iş olmasına karşın düzene kavuşmuş bir kent, iyi çıkarılmış yasaların yürütülmesini beceriksiz yöneticilere bırakırsa bu kişiler, bu iyi yasalardan yararlanmayıp maskara olmaktan öte, kente zararlar ve yıkımlar bile getirebilirler. ${ }^{70}$ Platon, yasaların devletin düzenlenmesinde gerekli olduğunu söylese de bu onun, yöneticilerin nitelikli olması gerektiği düşüncesinden uzaklaştığı anlamına gelmez. Bu açıdan o, işin ehline verilmesi ilkesi olan liyakati vurgulamaya devam etmektedir. Adil

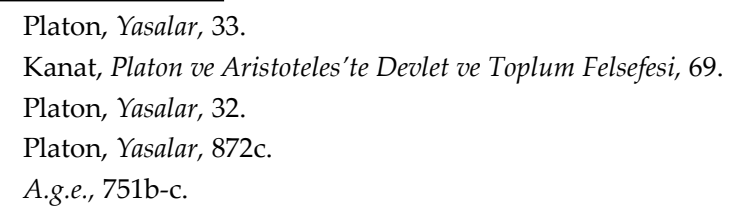


ve düzenli bir devlette hem doğru yasalar olmalıdır hem de yönetici nitelikli olmalidir.

Platon, yasaların önemini göstermek için ruh ile beden arasında bir analoji kurar. Nasıl ki ruh ve beden diye iki ayrı şey vardır, bu iki şeye uygun düşen bazı sanatlar vardır. Bedenle ilgili beden eğitimi ve hekimlik sanatlarına karşılık, siyaset başlığı altında da yasama ve yargılama sanatları vardır. Yargılama, beden eğitimine karşılık gelirken, hekimliğin karşılığı yasa koymadır. ${ }^{71}$ Bedenle ilgili bahsi geçen sanatların gayesi açıktır: bedenin sağlığı. Platon'a göre siyasetle ilgili sanatların amacı da erdemdir. Platon, Yasalar'da kanunların tek bir amaca bakması gerektiğini, bunun da erdem olduğunu açıkça dile getirir. ${ }^{72}$ Bu düşünce, Platon için oldukça anlaşılırdır çünkü kendisi siyasetin ruh için olduğunu belirtmiş ve ruh için iyiliğin de erdem olduğunu ileri sürmüştür.

Erdemi amaçlayan siyasetin bir kolu olan yasama, yurttaşların erdem kazanmasına aracılık eder. Yasa koyucunun yazıya geçirdiği yasalara, övgü ve kınamalara uyarak lekesiz bir hayat sürmüş kimseler erdemlidirler. ${ }^{73}$ Platon bu süreci psikolojik açıdan şu şekilde açıklar: İnsan zekâsı duygular ve inançlar çiftine bağlıdır. Bir yanda mevcut yaşamla ilgili zevk ve acı, diğer yanda geleceğe ilişkin ceza korkusu ve umut edilen zevk, insan zekâsını yönlendirir. Ruhu etkileyen bu dört faktöre sitede nomos, yani yasa eklenir. Sert ve karmaşık nitelikli "dört demir tel", ruhta "akıl" ve toplumda "genel yasa" adını taşıyan "kutsal altın tel" in beşinci çekimine direnir. Platon’a göre insanın her durumda itaat etmesi gereken tek çekim, akıl ve aklın toplum içindeki yansıması olan yasalardir. ${ }^{74}$

Yurttaşın yasa ile erdem kazanabilmesi, onun yasaya karşı itaatkâr olmasına bağlıdır. Platon, yasaya itaatin önemini vurgulamak için tanrılar tanrısı Zeus'un bile yasalara göre hükmettiğini söyler. ${ }^{75}$ Tanrıların tanrısı bile yasalara uygun hükmederek yasalara uyuyorsa, insan da yasaya uymalıdir. Platon, bir başka eserinde Sokrates'in kendisi hakkında verilen yargı kararı karşısındaki tavrını aktarır. Onun bu aktarımını yurttaşın yasaya itaati bağlaminda ele almak mümkündür. Sokrates, idam cezasından kaçması önerildiğinde, kaçmaya kalktığı takdirde yasaların ve devletin karşısına çıkarak ona bu yaptığının, giriştiği işin, kanunları da bütün bir devleti de yıkmak olup

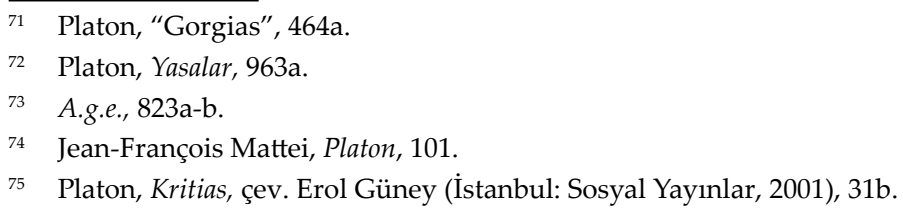


olmadığını sorduğunu farz eder. ${ }^{76}$ Şayet yurttaşlar, yargı kararlarını uygulamaz, onun hükümlerinden kaçmaya kalkarsa, verilen hükümlerin hiçbir gücü kalmayacaktır. Kişiler onları etkisiz kılar, siler atarsa devlet varlığını sürdüremeyip yıkılıp gidecektir. Bu nedenle yurttaşların devletin verdiği hükümlere uymaması, devleti yıkmaya kalkışmak anlamına gelir. ${ }^{77}$ Yurttaşların devlete borçlu olduğunu düşünen Sokrates'e göre yurttaşlar savaşta, mahkemede ve her yerde devletin buyruklarına boyun eğmelidir. Devlet, yurttaşlarının dünyaya gelmesini sağladığı, onları beslediği, eğittiği ve elindeki her şeyden yararlandırdığı için yurttaşların onun buyruklarına karşı çıkması çok büyük bir günahtır. ${ }^{78}$

Platon'un yurttaşlar için itaat yükümlülüğü getirdiği yasalar, yasa koyucunun akıl aracılığı ile belirlediği, toplumun gereksinimlerine uygun kurallar bütünüdür. Platon'a göre yasa ile akıl arasında doğrudan bir ilişki vardır. Toplumun tümü için geçerli olacak yasaların ancak aklın çabası ile çıkarabileceğini düşünen Platon, aklın her şeyin başı olduğunu, yasa da dahil olmak üzere her şeyi yarattığını savunur. Ona göre "akıl" (nous) ile "yasa" (nomos) sözcükleri etimolojik olarak birbiriyle ilişkilidir. ${ }^{79}$ Platon, bu şekilde yasa ile aklı açık bir şekilde birbiriyle ilişkilendirir. Onun yasa ile akıl arasındaki bağlantıyı göstermesi yasa kavramlaştırmasına yaptığı özgül katkıyı oluşturmaktadir. ${ }^{80}$

Platon'un yasa tasarısı, yurttaşların son derece mutlu ve birbirine karşı olabildiğince dost olmalarını amaçlar. İnsanlar arasında pek çok haksızlığın olduğu yerde dostluk olamaz, dostluk ancak haksızlıkların mümkün olduğu kadarıyla az sayıda ve önemsiz konular hakkında olduğu yerde var olabilir. ${ }^{81}$ Platon, insan ilişkilerini adalet kavramı açısından değerlendirirken, adalet olmadan insanlar arasında dostluk olamayacağı gerçeğini dile getirir. Gerçekten de haksızlığın olduğu yerde güvenden ve sevgiden bahsedilemediği için dostluk da mümkün olmamaktadır. Adalet, devletlerin ayakta kalması açısından olduğu kadar, insanlar arasında güvene dayalı sağlıklı ilişkilerin kurulabilmesi bakımından da gereklidir.

Bireyin mutluluğu için adaleti gerekli sayan Platon, her ne kadar devletçi

\footnotetext{
Platon, Kriton ya da Görev Üstüne, çev. Samih Rifat (İstanbul: Can Yayınları, 2020), 13.

77 Michael Rosen - Jonathan Wolff, Siyasal Düşünce, çev. Sevda Çalışkan - Hamit Çalışkan (Ankara: Dost Kitabevi, 2006), 113.

78 Platon, Kriton ya da Görev Üstüne, 13.

79 Platon, Yasalar, 34-36.

80 Kanat, Platon ve Aristoteles'te Devlet ve Toplum Felsefesi, 68.

81 Platon, Yasalar, 743c-d.
} 
gibi görünse de devletin, yönetimi altında yaşayan insanların mutlulukları için var olduğu görüşündedir. Yani onun için devlet kendi başına bir amaç değil, insanların mutluluğu için gerekli bir araçtır. Platon bunu "Seçeceğimiz insanlar ömürleri boyunca yalnız toplumun yararına işler görmüş, zararına olan şeylerden de kaçınmış insanlar olmalı." diyerek belirtir. ${ }^{82}$ Yine aynı eserinde "... bütün yurttaşlara mutluluk sağlayan bir devlet düşünüyoruz. Yoksa yurttan bazı kişileri seçip onları mutlu kılacak değiliz." demesi halkın mutluluğuna verdiği önemi göstermektedir. ${ }^{83}$ Açıkça görüldüğü üzere Platon'a göre devlet, bütün bir halkın iyiliğini gözetmelidir. Ruhun akıl kısmının, ruhun bütününün çıkarını gözetmesi gerektiği gibi devlet de tüm halkın menfaatini düşünmelidir. Bu durum, adil olmanın bir gereğidir. Bu nedenle bir devlet, kalıcı olmak ve yurttaşlarını insanî ölçüler içinde mümkün olduğu kadar mutlu etmek için onur ve cezaları doğru şekilde dağıtmalıdır. ${ }^{84}$ Devletin adaleti tesis etmesi, yasalar yoluyla mümkün olacaktır. Doğru yasalar adaleti ve beraberinde yasalara uyanların mutluluğunu, bütün iyi şeyleri sağlar. ${ }^{85}$ Dolayısıyla mutlu bir yönetim söz konusu olacaksa yasalar ve bu yasaları ortaya koyacak yasa koyucular da olacaktır. ${ }^{86}$

Yasa koyucunun yerine getirmesi gereken birtakım yükümlülükleri vardır. O, öncelikle insanların davranışlarındaki güzel olanı ve olmayanı belirlemeli ve insanlara öğretmelidir. Ardından yurttaşlar arasında alım-satım işlerinin nasıl olacağını ortaya koymalıdır. Yasalara uyanları ödüllendirmeli, uymayanlara belli caydırıcılar getirmelidir. Son olarak yasa koyucu, bütün bunların başına aklı başında ve doğru görüşle hareket eden koruyucular getirecektir. ${ }^{87}$ Adaletin sağlanması için yasa koyucunun varlığı ve ortaya koyduğu yasalar dışında bu yasaların uygulanmasından sorumlu yargı mensupları da gereklidir. Platon'a göre bu kişiler, adaleti sağlayabilmek için aklı başında, doğru görüşle hareket eden kimseler olmalıdırlar. $\mathrm{O}$, bu işi rastgele kimselere bırakmaz. Ancak adaletin sağlanması işi yalnızca yasa koyucu ve yargı mensuplarının sorumluluğunda değildir. Adaleti sağlama noktasında yurttaşa da yasalara itaat görevi düşmektedir.

Platon'a göre yasa, her şeyi açıkça ve yeterince söyleyememesine, bazı konulara değinip bazılarını söylemeden geçmesine rağmen elden geldiğince

\footnotetext{
82 Platon, Devlet, 412e.

83 A.g.e., 420c.

84 Platon, Yasalar, 697a-b.

85 A.g.e., $631 \mathrm{~b}$.

86 A.g.e., 709c.

87 A.g.e., 632a-c.
} 
hiçbir şeyi atlamamaya ve her konuya açıklık getirmeye çalışmalıdır. ${ }^{88}$ Unutulmamalıdır ki yasa ne denli kapsamlı olursa olsun, en iyi durumda bile bir genellemedir ve bu nedenle tüm özgül sorunlara yanıt veremeyecektir. ${ }^{89}$ Hayatın karmaşıklığı ve çok yönlülüğü olası her durumun düşünülmesini ve hakkında yasa yapılmasını imkânsızlaştırır. Platon, hiçbir konuyu atlamamaya çalışarak yasaların kapsamını oldukça geniş tutar ve evlilik, doğum, çocuk yetiştirme, eğitim ve devlet yöneticilerinin atanması gibi konular dışında çiftçilerle, çobanlarla, arıcılarla, bu ürünlerin koruyucuları ve ilgili araç gereçlerle ilgili yasal düzenlemeler yapılması gerektiğini söyler. ${ }^{90}$ Bu tür yazılı yasalar dışında yazılı olmayan yasalar da olacaktır. Yazılı olmayan yasalar, çok eski geleneklere dayanan kural ve düzenlemelerdir. Bu yasalar, çıkarılmış yasalar ile çıkarılacak yasalar arasında bir köprü işlevi görürler. Bunlar, doğru uygulandıkları takdirde çıkarılmış yazılı yasalara destek olurlar. ${ }^{91}$

Platon, bir devlet ne kadar adil ve iyi düzenlenmiş olursa olsun, yine de yasaya itaatsizlik edecek insanların var olacağının farkındadır. Bu nedenle eserlerinin bazılarında ceza konusuna yer vermiştir. Ona göre yasaların bir kısmı, insanların birbirleriyle ne şekilde ilişki kurarak dostluk içinde yaşayacaklarını öğretmek maksadıyla dürüst insanlar için çıkarılırken, bir kısmı da bu eğitimden kaçan, yaratılıştan sert, hiç yumuşamayan insanların tamamen kötülüğe gömülmemeleri için çıkarılır. ${ }^{92}$ Yasalar, iyi insanlar için adaletin korunup gelişmesini sağlarken, kötü insanlardan kusurları düzeltilebilir olanları bilgisizlikten, korkaklıktan, kısaca her tür adaletsizlikten kurtarıp bu kişileri elden geldiğince değiştirmeyi amaçlar. ${ }^{93}$ Yasalar, toplumdaki iyi ve kötü tüm insanlar göz önünde bulundurularak ortaya konurlar. Yasalarla bir yanda iyi insanların erdemleri güçlendirilmeye, diğer yanda da kötü insanlardaki kusurlar ortadan kaldırılmaya çalışılır.

Platon, ceza çekmeyi yanlış bir iş yapanın bu iş için doğru şekilde cezalandırılması olarak tanımlar. ${ }^{94}$ Platon'un suçlunun cezalandırılması gerektiğine ilişkin en ufak bir şüphesi bile yoktur. Tanrı ya da insan hiç kimse, haksızlığın cezalandırılmaması gerektiğini savunmaya kalkışmadı̆̆ı gibi suçlular bile haksızlık ettiklerinde cezadan kurtulmaları gerektiğini ileri sürmezler. Sadece

\footnotetext{
Platon, Yasalar, 809a-b.

Kanat, Platon ve Aristoteles'te Devlet ve Toplum Felsefesi, 71.

Platon, Yasalar, 843d-e.

A.g.e., 35.

A.g.e., $880 \mathrm{~d}-\mathrm{e}$.

A.g.e., 957e.

Platon, “Gorgias", 476e.
} 
suç işlemediklerini, yaptıkları şeyin suç olmadığını iddia ederler. ${ }^{95}$ Gerçekten de genelde suçluların savunmaları, masum oldukları, itham edildikleri suçu işlemedikleri iddiası üzerine kuruludur. Suçlular, suçun cezayı gerektirmediğini değil, o suçu işlemediklerini ileri sürerek kendilerini savunurlar.

Suçlulara ceza verilmesi gerektiği konusunda 1srarlı olan Platon, suçluların nasıl cezalandırılacağı meselesini haklı ve haksız ceza ayrımı üzerinden ele alır. $\mathrm{O}$, doğru veya haklı ceza ile doğru olmayan ya da haksız olan ceza arasında bir ayrım yapar. Ona göre haklı ceza, yanlışlık yapanın yanlışını düzeltmeyi ve düzeni yeniden kurmayı amaçlayan cezadır. ${ }^{96}$ Platon, doğru şekilde cezalandırılan kişinin bundan fayda sağlayacağını düşünür. Çünkü ceza gören kişinin ruhu kötülükten kurtulacaktır. ${ }^{97}$

Platon, cezayı hem suçu işleyen kişi hem de içerisinde suçun işlendiği toplum için gerekli görür. Doğru şekilde cezalandırma ile suçlu sslah edilecektir. Ayrıca site de düzene kavuşacaktır. Bu nedenle suçlu, cezanın kendi iyiliği için gerekli olduğunu bilmelidir. Cezadan kaçmayan suçlu, haklı cezadan yararlanabilecektir. Platon açısından hasta bir ruhla yaşamak, hasta bir bedenle yaşamaktan daha büyük bir mutsuzluktur. Hasta diye nitelenen ruh, bozuk ve kirli bir ruhtur. Kötülükler basamaklar halinde düşünüldüğünde doğru olmayan bir iş yapmak alt basamakta olan kötülüktür. Üst basamakta yer alan daha büyük kötülükse, doğru olmayan bir iş yapıp da cezalandırılmamaktır. Bu nedenle yanlış iş yapan kişi, gönüllü olarak ceza göreceği yere koşmalıdır. Hastanın hekime gitmesi gibi suç işleyen de kötülük hastalığının ruhuna yerleşmemesi, ruhunun iyileşemez bir duruma gelmemesi için yargıç karşısına çıkmalıdır..$^{98}$

Kişinin yaptığı adaletsizlik büyük de olsa küçük de olsa, yasa ona ders verecek ve bir daha böyle bir harekete hiçbir zaman kalkışmamaya ya da çok az yapmaya zorlayacaktır ve ayrıca o kişiye verdiği zararı da ödetecektir. Yasa, bunu haz veya acı vererek, onurlandırarak ya da onursuz kılarak, para cezası ile ya da ödül vererek yapabilir. Yasanın amacı, bu yollarla ya da başka bir yolla kişinin adaletsizlikten nefret etmesini veya adaletin özünü sevmesini sağlamaktır. Ancak yasa koyucunun karşısına iflah olmaz biri çıkabilir ki Platon bu tür insanlar için ölüm cezasının konulabileceğini düşünür. Ona göre bu tür kişiler için yaşamak daha iyi değildir. Onların öldürülmesi başkaları için

\footnotetext{
Platon, Euthyphron, çev. Pertev Nail Boratav (İstanbul: Sosyal Yayınlar, 2000), 8d-e.

Platon, Kritias, 106b.

Platon, "Gorgias", 478a.

98 Platon, "Gorgias", 479b-480b.
} 
adaletsizliğin sonuçlarına dair bir örnek olacağı gibi ayrıca kent, kötü insanlardan temizlenmiş olacaktır. ${ }^{99}$ Görüldüğü üzere Platon, bazı insanların idam edilmesi taraftarıdır. $\mathrm{O}$, hem toplum için bir örnek olup halkı adaletsizlikten uzaklaştıracağı hem de siteyi kötü insanlardan kurtaracağı gerekçesiyle idam cezasını onaylamaktadır. Ancak idam cezası, Platon için ceza türlerinden yalnızca birisidir. İdam dışında, işlenen suçun türüne göre sürgüne gönderme, mallarına el koyma gibi cezalar da uygulanabilir. Doğru oldukları takdirde bu tür cezalar vermek iyiyken, doğru olmadıklarında bu cezaları uygulamak kötüdür. ${ }^{100}$

Anlaşıldığı üzere Platon'a göre ceza, çoğu suçluya fayda sağlasa da cezanın çare olmadığı bazı insanlar vardır. En kötü cinayetlerden ötürü suçlu olanlar iyileşemez olanlardır. Bu kişiler uzun cezalar çekseler dahi cezadan yararlanıp iyi insanlar haline gelemezler. Bu nedenle bunların ceza görmesi bunlara bir fayda sağlamayacaktır. Fakat bunlar yine de cezalandırılmalıdırlar. Bu insanların en dayanılmaz, en acı, en korkunç ıstıraplara çarptırıldığını göstermek, diğer tüm kötüler için ibret alınacak birer örnek olur ve onlara bu şekilde iyilik eder. ${ }^{101}$ Cezanın doğru olmayan bir insan için yararlı olduğunu düşünen Platon, ceza ile ruhun kötülüklerden arınacağ1 ve suçlunun daha iyi bir insan olacağı iddiasındadır. Ancak durum genel olarak böyledir ve cezanın, ruhuna tesir etmediği, iyileştiremediği insanlar da vardır. Ceza bu insanları düzeltemese de gereklidir. Verilecek cezadan her ne kadar bu kişiler fayda görmeyecek olsalar da çektikleri istırapla toplumdaki kötü insanların gözü korkacak ve bu ceza onlar için caydırıcı olacaktır. Ceza konusunda Platon hem suç işleyeni hem de toplumun tümünü göz önünde bulundurur. İdeal olan her ikisinin de cezadan yarar sağlamasıdır. Ancak suçlunun cezadan fayda görmediği durumlarda bile verilecek ceza, toplum açısından yararlı olduğundan, ceza suçlunun değişimine hizmet etmediği durumlarda da meşru olmaktadır.

Cezanın bu şekilde suçluya ve topluma fayda sağlayabilmesi için onun doğru, yani haklı olması gerekir. Bu nedenle ceza verilirken cezanın haklı olması noktasında hassas olunmalıdır. Platon, bir insan herhangi bir suçla itham edilirken, ona isteyerek veya istemeyerek yanlış bir ceza vermekten olabildiğince çekinilmesi gerektiğini söyler. ${ }^{102}$ Onun bu ifadesi, cezanın adil

\footnotetext{
Platon, Yasalar, 354.

Platon, "Gorgias", 470a-c.

1 Platon, Devlet, 525b-c.

102 Platon, Yasalar, 944d-e.
} 
olabilmesi için işlenen suç ile verilen ceza arasında bir uygunluk olması gerektiği düşüncesini akla getirmektedir.

\section{Sonuç}

Evreni düzenli bir yapı olarak gören Platon, evren ile insan ruhu ve site arasında bir benzerlik kurar ve bu çerçevede insanın ve toplumun nasıl düzen kazanacağını açıklamaya koyulur. Diğer eserlerinde de "adalet" konusuna bir şekilde yer veren Platon, adalet konusunu özellikle Devlet ve Yasalar adlı kitaplarında tartışır. Adaleti, tanrısal bir ilke olarak gören ve birkaç açıdan tanrılarla ilişkilendiren Platon'a karşın modern dünyada adalet kavramı tanrı ile hiçbir şekilde ilişkilendirilmeden, seküler bir kavrayışla ele alınmaktadır. Modern dünyada adaletin ne tanrılarla bir ilgisi olduğu ne de onun evrensel düzene uymanın bir sonucu olduğu düşünülür. Atomik birey anlayışı ve mekanik evren tasavvuru hâkim olduğu için kişi, kendisini evrensel bir düzenin parçası olarak hissetmemektedir. Bu nedenle adalet, evrenin düzeni ile ilgili bir konu olarak düşünülmemektedir. Günümüzde adalet yalnızca mevki, makam, para vb. maddi değerlerin ne şekilde dağıtılacağı ve suçlulara ne tür cezalar verilmesi gerektiği meselelerinden ibaret siyasi ve toplumsal bir mevzu olarak görülmektedir. Bunun yanı sıra modern dünyada adalet bireysel bir mesele olmaktan çok, devletin yerine getirmesi gereken bir yükümlülük sayılmaktadır. Bireyler, adaleti kendi ruhlarının düzen kazanması olarak görmezken ve bunun neticesi olarak kişisel kararlarında ve eylemlerinde ne kadar adaletli olduklarını dikkate almazken, devletlerinin her işte adil olmasını beklemektedir. Bu açıdan bakıldığında modern adalet anlayışının, Platon'unkine göre daha dar bir kapsama sahip olduğu söylenebilir.

Platon, insan ruhu ile toplumu üç kısımdan müteşekkil bir yapı olarak görür. İnsan ruhu, arzu ve isteklerin bulunduğu iştaha, öfke gücü ve düşünen akıldan oluşurken, toplum da bunlara karşılık gelen üretici sınıf, koruyucu sınıf ve yönetici sınıftan meydana gelir. Ruhtaki ve toplumdaki her kısmın yetenekleri ve bu yeteneklere uygun şekilde yerine getirmeleri gereken görevleri vardır. Bunların her birinin kendi sınırları içinde kalarak üzerlerine düşen işleri yapması, bu parçaların erdem sahibi olmasını sağlarken, içinde bulundukları yapının da düzen kazanmasına neden olur. Her kısmın kendi işlevini yerine getirdiği bir yapı düzenli ve adil bir yapıdır. Bunun neticesi ise bireysel ve toplumsal mutluluktur. Ancak bu mutluluk bilgelik sahibi bir akıl olmadan sağlanamaz.

Bireysel olarak yalnızca filozoflar kendi başlarına mutluluğa ulaşabilirler. Azınlıkta kalan bu küçük grup, iştaha için gerekli erdem olan ölçülülüğe, öfke 
gücü için gerekli erdem olan cesarete ve akıl için gerekli olan bilgeliğe sahip olduğu için bunun bir sonucu olarak adalet erdemine de sahip olur. Toplumun geri kalan çoğunluğu ise, bilgelikten mahrum olduğu için kendi başına adalete ulaşamaz. Bu kişiler akıl tarafından değil, ruhun akıllı olmayan diğer kısımları tarafından yönetilirler. Buna rağmen bu insanlar da filozofun yönetimi altında adalete erişebilirler. Filozoflar, kendilerini akıl ile yönettikleri gibi yönetici olarak da bir siteyi aynı akıl ile yönetebilir ve tıpkı kendilerine düzen, adalet ve mutluluk sağladıkları gibi topluma da bu değerleri katabilirler. Bu nedenle filozofların yönetici olması, toplumların düzen, adalet ve mutluluk kazanması için olmazsa olmazdır. Bu kişiler, bilgelik erdemine sahip olan akılları ile topluma bütünün iyiliğini gözeterek faydalı olurlar. Akıl, ruhta ruhun tüm kısımlarının iyiliğini gözeterek, toplumda ise bütün toplumsal kesimlerin iyiliğini amaçlayarak adaleti sağlar. Bütünün iyiliğini gözetmek, adaletin temel koşullarından biridir. Bu nedenle adalet, asla yöneticinin veya bir başkasının özçıarına indirgenemez. Platon'un bu görüşleri, insanların adil olmalarını engelleyen en etkili unsurun özçıkar kaygısı olduğunu göstermektedir. İnsanlar genelin iyiliği pahasına özçıkarlarını gözeterek eylemde bulunduklarında adaletten uzaklaşmaktadırlar. Ayrıca bireylerin adalet uğruna zaman zaman bazı fedakârlıkta bulunmaları gerekebilmektedir. Özçıkar kaygısı ise bu tür fedakârlıklara mani olarak adaletin tesisini engeller.

Platon'a göre toplumda adaleti sağlayacak kişiler öncelikle bilge kimselerdir ve bilge bir insan olmak hiç de kolay değildir. Kişinin bilgelik erdemini kazanabilmesi için hem yaradılıştan buna uygun olması hem de uzun ve sıkı bir eğitim almış olması gerekir. Ancak toplumsal adaletin sağlanması yalnızca yöneticinin işi değildir. Adaletin sağlanmasından toplumun tümü sorumludur. Adil bir toplum için yalnızca yönetici değil, siteyi oluşturan bütün toplumsal kesimler sitenin tamamı için iyi olacak işi yapmalıdır ki bu iş, her birey için o kişinin en yetenekli olduğu iştir. Toplumsal rollerin dağıtılmasında kişisel tercih ve özgürlüğe yer vermeyen Platon, liyakat vurgusu ile dikkat çeker. Platon, toplumdaki mevki ve makamların verilmesinin kişilerin isteklerine göre değil, kabiliyetlerine göre olması gerektiğini söyleyerek liyakati esas alır. Ona göre bu, toplumsal düzen ve mutluluk için elzemdir. Gerçekten de insanların kendilerine en uygun işi yapmaları hem onların hayatlarını tatmin edici kılmakta hem de toplumsal gelişime katkı sağlamaktadır. Bu nedenle insanların kendileri için en uygun işi yapmalarının bireysel ve toplumsal açıdan oldukça önemli olduğu görülmektedir.

Platon, adil bir devlet için yöneticinin nitelikli olmasının dışında doğru yasaların mevcudiyetini de gerekli görür. Yasalar, toplumda adaletin tesis 
edebilmesi için gerekli kurallardır ve onların akıl kaynaklı olması şarttır. Yönetim, eğitim, tarım, suç vb. konular ile ilgili yasalar ortaya koyarak toplumsal hayatı düzenler. Yasaların amacı, haksızlıkları engelleyerek toplumda dostluk ilişkilerinin korunmasını sağlamaktır. Toplumun mutluluğunu amaçlayan herkes bunlara itaat etmekle yükümlüdür. Kuşkusuz hayatın tüm alanlarını yazılı yasalarla düzenlemek mümkün değildir. Bu nedenle yazılı yasalar, yazılı olmayan yasalar tarafından desteklenir. Ancak yazılı olmayan yasalara körü körüne itaat edilmemeli, bunlar akıl süzgecinden geçirilerek uygulamaya konulmalıdır. Platon'un yasaların kaynağının akıl olduğunu vurgulaması, yazılı olmayan yasalarda da akla uygunluğun aranması gerektiğini göstermektedir.

Platon'a göre çok hoş bir konu olmamakla birlikte suçlulara verilecek cezaların da yasalar ile belirlenmesi gerekir. Suçluların cezalandırılmaması, hem suçlu için hem de toplum için büyük kötülüktür. Suçlunun cezalandırılması gerektiği herkesin, hatta suçluların nezdinde bile apaçıktır. Haklı ceza ile suç işleyenin ruhu iyileşeceği gibi toplum da içindeki kötü insanların kötülükten cayması nedeniyle verilen cezadan fayda görecektir. Suçlunun cezalandırılması suçluyu islah ederken, toplumu da korur. Ancak Platon, tüm suçluların cezalandırılması gerektiğini söylese de bunların hepsinin iyileştirilebilir olduğunu düşünmez. Bu kişiler için idamın uygun bir ceza olduğunu söyleyen Platon, idam cezasını ıslah olması mümkün olmayan insanlar için gerekli görmektedir. Islah olamayacak insan fikri, tartışılmaya değer bir konudur. Kötülük yapan her insanın düzelip düzelemeyeceği, düzelebilecek insanların da hangi şartlarda düzelebileceği siyaset, hukuk, psikoloji ve eğitim gibi alanlar açısından son derece önemli sorulardır. Günümüzde suçlulara verilen cezalarda ve bu cezaların veriliş nedenlerinde görülen farklılıklar, ayrıca idam cezası ile ilgili tartışmalar bu sorulara henüz yeterince tatminkâr yanıtlar verilemediğini göstermektedir.

Görüldüğü üzere Platon düşüncesinde "adalet" kavramı bir dizi başka kavramla iç içedir. Adalet, Platon için bireysel ve toplumsal düzlemlerde benzer şekilde ortaya çıkan bir erdemdir. Adaletin ortaya çıkabilmesi için bireylerin ve toplumların akıl tarafından yönetilmesi gerekir. Filozofun aklı, sağladığı düzenle hem filozofun hem de toplumun adaletli olmasını sağlar ki mutluluk yalnızca bu düzen ve adaletle mümkündür. Filozof adaleti çıardığı yasalar ile tesis eder. Platon'a göre yasalar, adalet için birer araçtırlar. Ancak bunun için yasaların doğru ve haklı yasalar olması gerekir. Bu nedenle yasalar keyfi değil, akıl kaynaklı olmalıdır. Bu görüşleriyle Platon, adaleti başta düzen ve yasa olmak üzere bilgelik, ruh, akıl, toplum, erdem, düzen, mutluluk, eğiyim 
ve ceza kavramları ile ilişkilendirmiş ve kapsamlı bir adalet anlayışı ortaya koymuştur.

\section{Kaynakça}

Abramson, Jeffrey. Minevra'nın Baykuşu/Batı Siyasi Düşünce Tarihi. çev. İbrahim Yıldız. İstanbul: Dipnot Yayınları, 2014.

Adanalı, Yurdagül K. “Düzen mi Anarşi mi?”. Felsefeye Giriş/Temel Problemlere Sistematik Yaklaşım. ed. Murat Arıcı. Ankara: Nobel Akademik Yayıncilık, 2019.

Akdemir, Ebamüslim. İnsan Felsefesi/Epiktetos ve Marcus Aurelius Örneği. İstanbul: Birey Yayıncılık, 2010.

Arslan, Ahmet. İlkçağ Felsefe Tarihi 2. İstanbul: İstanbul Bilgi Üniversitesi Yayınevi, 2018.

Badiou, Alain. Platon'un Devleti. çev. Savaş Kılıç - Nihan Özyıldırım. İstanbul: Metis Yayınları, 2015.

Blackburn, Simon. Devlet ve Platon. çev. Merve Yüksel - Müzeyyen Baturay. Ankara: Versus Kitap, 2014.

Brun, Jean. Platon ve Akademia. çev. İsmail Yerguz. Ankara: Dost Kitabevi, 2007.

Cevizci, Ahmet. Etik/Ahlak Felsefesi. İstanbul, Say Yayınları, 2018.

Cohen, Martin. Platon'dan Mao'ya Siyaset Felsefesi. çev. Hamdi Bravo. Ankara: Fol Kitap, 2020.

Erkızan, Hatice Nur - Çüçen, A. Kadir. Felsefe Tarihi I/Antik Çă̆ ve Orta Çă̆ Felsefesi Tarihi. Ankara: Sentez Yayıncilık, 2013.

Geuss, Raymond. Sokrates'ten Adorno'ya Felsefe. çev. İbrahim Yıldız. İstanbul: Dipnot Yayınları, 2019.

Havelock, Eric Alfred. Platon/ Filozof Şaire Karşı. çev. Adem Beyaz. İstanbul: Pinhan Yayıncılık, 2015.

Kanat, Celal A. Platon ve Aristoteles'te Devlet ve Toplum Felsefesi. İstanbul: Doruk Yayımcllık, 2013.

Kenny, Anthony. Batı Felsefesinin Yeni Tarihi I/Antik Felsefe. çev. Serdar Uslu. İstanbul: Küre Yayınları, 2018.

Lane, Jeremy F. “Ranciére'in Anti-Platonculuğu: Eşitlik, “Yetim Mektup” ve Sosyal Bilimlerin Sorunsalı". çev. Erdem Baykal, Yaşayan Platon/Çağdaş Fransız Felsefesinde Platon Okumaları. ed. Sadık Erol Er - Birdal Akar. Konya: Çizgi Kitabevi, 2017.

MacIntyre, Alasdair. Homerik Çă̆dan Yirminci Yüzyıla Ethik'in Kısa Tarihi. çev. Hakkı Hünler - Solmaz Zelyüt Hünler. İstanbul: Paradigma Yayınları, 2001.

Mattei, Jean-François. Platon. çev. İsmail Yerguz. Ankara: Dost Kitabevi, 2008.

Mutlu, Barış. "Platon'un Devlet'inde Filozofun/Filozofların Kral Olması Adil midir?", Özne 24 (2016), 145-166.

Platon. Euthyphron. çev. Pertev Nail Boratav. İstanbul: Sosyal Yayınlar, 2000.

Platon. Sofist. çev. Cenap Karakaya. İstanbul: Sosyal Yayınlar, 2000.

Platon. Kritias. çev. Erol Güney. İstanbul: Sosyal Yayınlar, 2001.

Platon. Meneksenos. çev. İrfan Şahinbaş. İstanbul: Sosyal Yayınlar, 2001.

Platon. Timaios. çev. Erol Güney - Lütfi Ay. İstanbul, Sosyal Yayınlar, 2001. 
Platon. Devlet. çev. Sabahattin Eyüboğlu - M. Ali Cingöz. İstanbul: Türkiye İş Bankası Kültür Yayınları, 2005.

Platon. Yasalar. çev. Candan Şentuna - Saffet Babür. İstanbul: Kabalcı Yayınevi, 2007.

Platon. “Gorgias”. Diyaloglar. çev. Melih Cevdet Anday. İstanbul: Remzi Kitabevi, 2009.

Platon. Kriton ya da Görev Üstüne. çev. Samih Rifat. İstanbul: Can Yayınları, 2020.

Rescher, Nicholas. 101 Anekdotta Felsefe Tarihine Yolculuk. çev. Abdullah Y1lmaz. İstanbul: Vakıfbank Kültür Yayınları, 2019.

Rosen, Michael - Wolff, Jonathan. Siyasal Düşünce. çev. Sevda Çalışkan - Hamit Çalışkan. Ankara: Dost Kitabevi, 2006.

Russell, Bertrand. Batı Felsefesi Tarihi I. çev. Muammer Sencer. İstanbul: Say Yayınları, 2002.

Taylor, Alfred Edward. Platon/Bilgi, Ruh ve Devlet. çev. Cengiz İskender Özkan. Ankara: Fol Kitap, 2020.

Urhan, Veli. “Platon'un Siyaset Felsefesinde İdeal Devlet”. Özne 24 (2016), 193-206.

Weinstein, Joshua I. "Platon'un Devlet'inde Adalet Mutluluk Getirir", çev. Mustafa Topal, Batı Felsefesindeki 100 Temel Mesele. ed. Kıvanç Koçak. İstanbul: İletişim Yayınları, 2014.

Zeller, Eduard. Grek Felsefesi Tarihi. çev. Ahmet Aydoğan. İstanbul: Say Yayınları, 2008. 